\title{
Comparison of Chemical and Functional Properties of Stevia rebaudiana (Bertoni) Varieties Cultivated in Mexican Southeast
}

\author{
Maira Segura-Campos ${ }^{1}$, Enrique Barbosa-Martín ${ }^{1}$, Ángel Matus-Basto ${ }^{1}$, Diana Cabrera-Amaro ${ }^{2}$, \\ María Murguía-Olmedo ${ }^{2}$, Yolanda Moguel-Ordoñez ${ }^{2}$, David Betancur-Ancona ${ }^{{ }^{*}}$ \\ ${ }^{1}$ Facultad de Ingeniería Química, Universidad Autónoma de Yucatán, Yucatan, Mexico; ${ }^{2}$ Instituto Nacional de Invesigaciones \\ Forestales, Agrícolas y Pecuarias (INIFAP), Yucatan, Mexico. \\ Email: bancona@uady.mx
}

Received October 25 ${ }^{\text {th }}, 2013$; revised December $22^{\text {nd }}, 2013$; accepted January $16^{\text {th }}, 2014$

Copyright (C) 2014 Maira Segura-Campos et al. This is an open access article distributed under the Creative Commons Attribution License, which permits unrestricted use, distribution, and reproduction in any medium, provided the original work is properly cited. In accordance of the Creative Commons Attribution License all Copyrights (C) 2014 are reserved for SCIRP and the owner of the intellectual property Maira Segura-Campos et al. All Copyright (C) 2014 are guarded by law and by SCIRP as a guardian.

\section{ABSTRACT}

The leaf powders from two varieties of Stevia rebaudiana (Bertoni) cultivated in Yucatan, Mexico were analyzed for their proximate composition, dietary fiber composition and functional properties. The leaf powders were a good source of carbohydrates $(64.06 \%-67.98 \%)$, protein $(12.11 \%-15.05 \%)$, and crudefiber $(5.92 \%-9.52 \%)$. Total dietary fiber content in the S. rebaudiana leaf powders were 28.61 (Morita II) and 29.12 (Criolla) g/100g sample, with most of this content represented by insoluble dietary fiber $87.79 \%$ (Morita II) and $70.02 \%$ (Criolla). Neutral detergent fiber (NDF), acid detergent fiber (ADF) and acid detergent lignin (ADL) were higher in Criolla $(19.29 \%, 17.77 \%, 8.98 \%)$ than Morita II variety $(18.11 \%, 14.16 \%, 2.28 \%)$. Hemicellulose and cellulose were higher in Morita II $(3.96 \%, 11.78 \%)$ than criolla variety $(1.51 \%, 8.79 \%)$. Functional properties of leaf powder from Morita II and Criolla were, water-holding capacity ( 2.87 - $4.07 \mathrm{~g} / \mathrm{g}$ sample), oil-holding capacity (6.49 - 6.79 g/g sample), water-absorption capacity ( 3.41 - $3.44 \mathrm{~g} / \mathrm{g}$ sample), water-adsorption capacity (0.25 - $0.28 \mathrm{~g} / \mathrm{g} \mathrm{sam}$ ple), and organic molecule absorption capacity (1.13 - $1.81 \mathrm{~g} / \mathrm{g}$ sample). These suggest that $S$. rebaudiana (Bertoni) leaf powders may be used as dietary supplement or as food additive.

\section{KEYWORDS}

\section{Stevia rebaudiana (Bertoni); Physico-Chemical Properties; Dietary Fiber; Functional Properties}

\section{Introduction}

Stevia is a perennial shrub that extensively grows in places like Brazil, Central America and Israel but is native to Paraguay. The genus Stevia belongs to Asteraceae family, tribe Eupatoriae and comprises of 240 species. This plant grows mostly at the altitude of 500 - $3000 \mathrm{~m}$ above sea level in semidry mountainous terrain. Different species of Stevia contain several potential sweetening compounds; Stevia rebaudiana (Bertoni) is the sweetest of all [1]. For centuries this herbal sweetener has been used in native cultures to counteract the bitter taste of

"Corresponding author. various plant based medicines and beverages. Nowadays the extraction of sweeteners from stevia leaves is a growing industrial and commercial worldwide sector; more than 750 tons of stevia leaves per year are used as crude extract for consumption and extraction of glycosides [2]. The sweetening property is associated with their contents of several glycosides, stevioside, steviobioside, rebaudiosides A to F, dulcoside A and steviol. These glycosides and their derivatives are known to account for $4 \%-20 \%$ of the dry weight of stevia leaves [3].

Stevia and its extract have been studied widely from the sweetener point of view. However, a search through literature show little information on the no-sweetening 
components that make up $80 \%-90 \%$ dry weight of this plant [4] and no information for varieties adapted for cultivation in Mexico. Green vegetables have long been recognized as the cheapest and most abundant potential sources of proteins, starch, dietetic fiber and other micronutrients because of its ability to synthesize these kinds of compounds from a wide range of easily available primary materials such as water, carbon dioxide, and atmospheric nitrogen [5]. According to Aletor and Adebayo [6], leaves and leaf protein concentrates could be used to improve not only the nutritional contribution of food products but also their functional properties. This means that stevia leaf powder or the residue obtained after extraction of sweetening components could be used as additives for the food industry.

Therefore the objectives of this study were to characterize the proximal content, dietary fiber composition and functional properties of the Stevia rebaudiana (Bertoni) leave powder cultivated in Yucatan, Mexico.

\section{Materials and Methods}

\subsection{Raw Material and Chemicals}

Stevia rebaudiana (Bertoni) varieties (Morita II and Criolla) were obtained from plots established in Yucatan, México (Figure 1). The plantation had a crop management according to the production technology described by Ramirez et al. [7]. Samples were obtained from the first cut of the plot at an age of three months; samples consisted on branches of leaves and stems. All chemicals were reagent grade or better and purchased from Sigma Chemical Co. (St. Louis, MO, USA).

\subsection{Proximate Composition}

The proximate composition of $S$. rebaudiana leaf powders were determined using AOAC [8] methods: moisture content (Method 925.09), ash (Method 923.03), crude fat (Method 920.39), crude protein using a 6.25 nitrogen-protein conversion factor (Method 954.01) and crude fiber (Method 962.09). The carbohydrate content was estimated as the nitrogen-free extract (NFE).

\subsection{Total Dietary Fiber}

This parameter was determined with the gravimetric enzymatic method proposed by Prosky et al. [9]. Briefly, 1 $\mathrm{g}$ of sample was weighed into each of four flasks and 50 $\mathrm{mL}$ of phosphate buffer (50.0 mM, pH 6) were added to each. The flasks were then placed in a water bath at $100^{\circ} \mathrm{C}, 0.1 \mathrm{~mL}$ of thermostable $\alpha$-amylase enzyme (Sigma A-3306) was added to each and then they were agitated at $60 \mathrm{rpm}$ for $15 \mathrm{~min}$. After cooling, $\mathrm{pH}$ was adjusted to 7.5. The flasks were returned to the bath at $60^{\circ} \mathrm{C}$, $0.1 \mathrm{~mL}$ protease (Sigma P-3910) added to each and then they were agitated at $60 \mathrm{rpm}$ for $30 \mathrm{~min}$. After cooling, $\mathrm{pH}$ was adjusted to 4.0. The flasks were again placed in the bath at $60^{\circ} \mathrm{C}, 0.3 \mathrm{~mL}$ amyloglucosidase (Sigma A-9913) added and then they were agitated for $30 \mathrm{~min}$. Finally, ethanol $95 \%(\mathrm{v} / \mathrm{v})$, preheated to $60^{\circ} \mathrm{C}$, was added at a $1: 4(\mathrm{v} / \mathrm{v})$ ratio. In a vacuum, flask content was filtered into crucibles containing celite (Sigma C-8656). The residue remaining in the flask was washed three times with $20 \mathrm{~mL}$ of ethanol $78 \%(\mathrm{v} / \mathrm{v})$, twice with 10 $\mathrm{mL}$ of ethanol $95 \%(\mathrm{v} / \mathrm{v})$ and twice with $10 \mathrm{~mL}$ acetone. Crucible content was dried at $105^{\circ} \mathrm{C}$. Protein $(\mathrm{N} \times 6.25)$ was determined for the residue in two crucibles and the residue in the remaining two was burned at $550^{\circ} \mathrm{C}$ for $4 \mathrm{~h}$.

$$
\begin{aligned}
& \operatorname{TDF}(\%)= \\
& \frac{[\text { Residue weight }(\mathrm{g})]-\operatorname{protein}(\mathrm{g})-\operatorname{ash}(\mathrm{g}) \times 1000}{\text { Sample weight }(\mathrm{g})}
\end{aligned}
$$

\subsection{Insoluble Dietary Fiber (IDF)}

This was determined following the method of Prosky et al., [9], which is similar to that for TDF, except that addition of ethanol $95 \%(\mathrm{v} / \mathrm{v})$ at $1: 4(\mathrm{v} / \mathrm{v})$ is omitted.

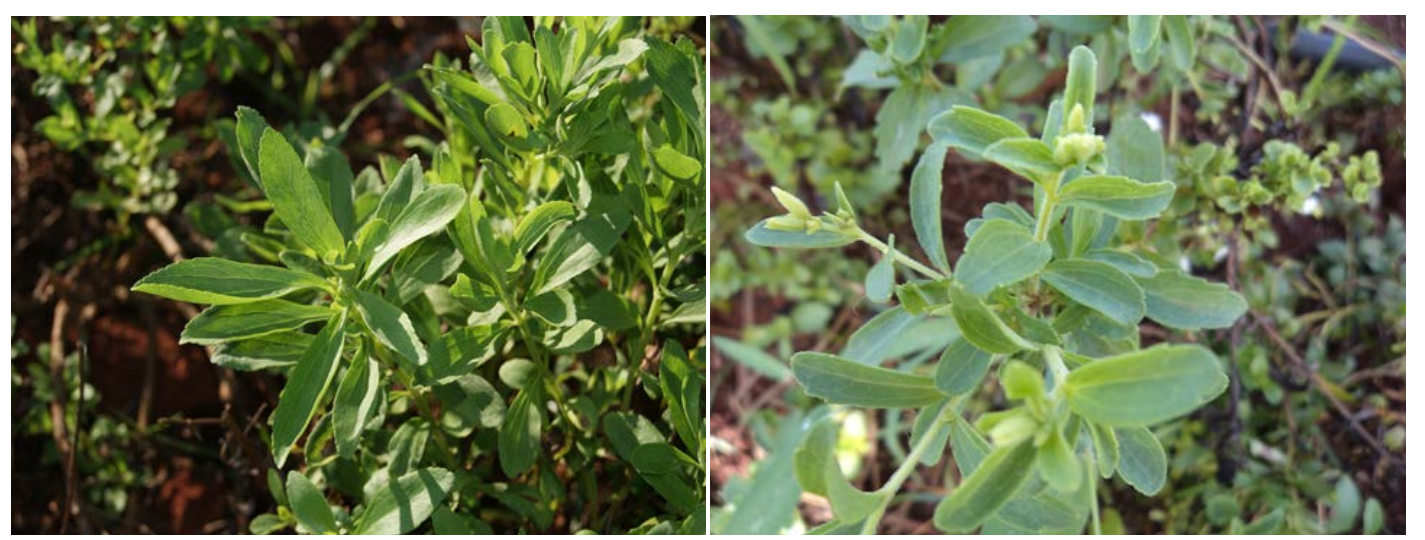

Figure 1. Morita II and Criolla Stevia rebaudiana varieties, respectively. 


\subsection{Soluble Dietary Fiber (SDF)}

Calculated by the difference between TDF and IDF:

$$
\text { SDF }(\%)=\text { TDF }- \text { IDF. }
$$

\subsection{Fiber Components}

\subsubsection{Acid Detergent Fiber (ADF)}

Samples were oven dried at $55^{\circ} \mathrm{C}$ to dry matter, then ground to pass a $1 \mathrm{~mm}$ screen. Dry $50 \mathrm{~mL}$ fritted glass crucibles overnight at $100^{\circ} \mathrm{C}$ and hot weigh (W1), recording weight to nearest $0.1 \mathrm{mg}$. Thoroughly sample was weighted (W2) (approximately 0.9 to $1.1 \mathrm{~g}$, record weight accurate to $0.1 \mathrm{mg}$ ) into Berzelius beaker. A volume of $100 \mathrm{~mL}$ acid-detergent solution (20 g of Cetyltrimethylammonium bromide technical grade in $1 \mathrm{~L}$ of sulfuric acid $1.0 \mathrm{~N}$ ) was added at room temperature. Sample was heat to boiling in 5 - $10 \mathrm{~min}$; heat was reduced to avoid foaming as boiling begins. The sample was refluxed $60 \mathrm{~min}$ from onset of boil, adjusting boiling to slow, even level. After $30 \mathrm{~min}$, using a minimal amount of acid detergent solution, the beaker was washed. The sample was filtered through tared fritted glass crucible, using minimal vacuum. The Berzelius beaker was washing with boiling water while inverted over the crucible to insure quantitative transfer of all fiber particles into the crucible. The residue was rinse twice with $30-40 \mathrm{~mL}$ acetone by filling crucible each time with vacuum off, allowing a minimum of 15 to $30 \mathrm{sec}(2 \mathrm{~min}$ recommended) before vacuuming dry. Finally the residue was dried overnight in forced-air oven at $100^{\circ} \mathrm{C}$ and weigh hot, recording weight (W3) to nearest $0.1 \mathrm{mg}$. Percent Acid Detergent Fiber (ADF) was calculated as follows [10]:

$$
\% \operatorname{ADF}(\mathrm{DM} \text { basis })=(\mathrm{W} 3-\mathrm{W} 1 / \mathrm{W} 2) \times 100
$$

where:

$\mathrm{W} 1=$ tare weight of crucible in grams,

$\mathrm{W} 2$ = initial sample weight in grams,

W3 = dry weight of crucible and dry fiber in grams.

\subsubsection{Neutral Detergent Fiber (NDF)}

Samples were processed similar than method reported for ADF using a volume of $100 \mathrm{~mL}$ neutral-detergent solution. The solution was prepared with distilled water, sodium borate, EDTA, lauryl sulfate, 2-ethoxyethanol and disodium phosphate. The $\mathrm{pH}$ was adjusted at $6.9-7.1$ [10].

\subsubsection{Acid Detergent Lignin (ADL)}

Samples were processed similar than method reported for ADF using a volume of $100 \mathrm{~mL} 72 \% \mathrm{H}_{2} \mathrm{SO}_{4}$ solution. The crucible with sample was ignited in a muffle furnace at $500^{\circ} \mathrm{C}$ for 2 hours. The crucible was weighted to the nearest $0.1 \mathrm{mg}$ (W3) [11].

\subsubsection{Cellulose and Hemicellulose}

These parameters were calculated as follows:

\%Cellulose $=$ ADF (Cellulose, lignin, cutin) - ADL (Lignin, cutin);

\%Hemicellulose $=$ NDF (Hemicellulose, cellulose, lignin, cutin) - ADF (Cellulose, lignin, cutin).

\subsection{Water-Holding (WHC) and Oil-Holding Capacity (OHC)}

Both capacities were determined following Chau et al. [12]. Briefly, $1.0 \mathrm{~g}$ (d.b.) of sample was weighed and then stirred into $10 \mathrm{~mL}$ distilled water or corn oil (density $=0.89 \mathrm{~g} / \mathrm{mL}$ ) for $1 \mathrm{~min}$ in a vortex. These suspensions were centrifuged at $2200 \times \mathrm{g}$ for $30 \mathrm{~min}$ and supernatant volume measured. Water-holding capacity was expressed as $g$ of water held per $g$ of sample, and oil-holding capacity as $g$ of oil held per $g$ of sample.

\subsection{Water Absorption Capacity}

The procedure of Chau et al. [12] was used. $10 \mathrm{~mL}$ of water added to $1.0 \mathrm{~g}$ (d.b.) of sample, the suspension was then stirred using magnetic stirrer for $5 \mathrm{~min}$, the suspension was transferred into centrifuge tubes and centrifuged at $2000 \times \mathrm{g}$ for $30 \mathrm{~min}$. The supernatant obtained was measured using a $10 \mathrm{ml}$ measuring cylinder. The density of the water was assumed to be $1 \mathrm{~g} / \mathrm{mL}$. The water absorbed was calculated as the difference between the initial water used and the volume of the supernatant obtain after centrifuging. The result was expressed as $\mathrm{g}$ of water per $g$ of sample.

\subsection{Water Adsorption Capacity}

This property was determined according to Chen et al. [13]. Briefly, $1.0 \mathrm{~g}$ (d.b.) of sample was placed in an equilibrium micro-environment at $98 \%$ relative humidity, generated by placing $20 \mathrm{~mL}$ of saturated potassium sulfate saline solution in tightly sealed glass flasks and placing these in desiccators at $25^{\circ} \mathrm{C}$. The sample was left in the microenvironment until reaching constant weight (72 h). Water adsorption capacity was expressed as g of water per $\mathrm{g}$ of sample.

\subsection{Organic Molecule Absorption Capacity}

Organic molecule absorption capacity was determined according to Zambrano et al. [14]. A 3.0 g (d.b.) sample was placed in an excess quantity of corn oil (approx. 10 $\mathrm{mL}$ ) for $24 \mathrm{~h}$ at $25^{\circ} \mathrm{C}$, and then centrifuged at $2000 \times \mathrm{g}$ and $25^{\circ} \mathrm{C}$ for 15 min. Organic molecule absorption capacity was expressed as the absorbed hydrophobic com- 
ponent and calculated in terms of sample weight gain ( $\mathrm{g}$ oil/g sample).

\subsection{Statistical Analysis}

Three replicates were performed for each study. All results were analyzed using descriptive statistics with a central tendency and dispersion measures. One-way ANOVAs were run to evaluate proximate composition, dietaryfiber contentand functional properties. All analyses were done according to Montgomery [15] and processed with the Statgraphics Plus version 5.1 software.

\section{Results and Discussion}

\subsection{Proximate Composition}

On dry weight basis, ash, protein and carbohydrate content of $S$. rebaudiana leaf powders were found to be higher whereas fat and crude fiber was estimated to be less (Table 1). The differences in the proximal components of both varieties could be explained by different growth conditions, as described by Rahmesh et al. [16].

Ash content is associated with the amount of minerals contained in a sample; these minerals are involved in all aspects of growth, health and reproduction, participating also in the formation of cells, tissues and organs [17]. Mishra et al. [18] reported an ash content of $11 \%$ for leaves of $S$. rebaudiana from India with a significant content of macronutrients like Ca (464 mg/100g), P (11 $\mathrm{mg} / 100 \mathrm{~g}), \mathrm{Na}(190 \mathrm{mg} / 100 \mathrm{~g}), \mathrm{K}(1800 \mathrm{mg} / 100 \mathrm{~g})$, and Mg (349 mg/100g); and micronutrients like Fe (55 $\mathrm{mg} / 100 \mathrm{~g})$ and $\mathrm{Zn}(1.5 \mathrm{mg} / 100 \mathrm{~g})$. Varieties of $S$. rebaudiana cultivated in Mexico contain high amounts of ashes (Table 1), so that could be an important source of macro and micronutrients. The proximal component of lower content was fat 3.23\% (Morita II) and 3.04 (Criolla). Tadhani and Subhash [19] reported a fat content of $4.34 \%$ for leaves of S. rebaudiana from India; these authors identified six fatty acids (palmitic, palmitoleic, stearic, oleic, linoleic and linolenic acids) in the leaf oil

Table 1. Proximate composition of Stevia rebaudiana (Bertoni) varieties (\% d.b.).

\begin{tabular}{ccc}
\hline Component & Morita II & Criolla \\
\hline Moisture & $(7.45)^{\mathrm{b}}$ & $(7.80)^{\mathrm{a}}$ \\
Ash & $7.82^{\mathrm{b}}$ & $11.93^{\mathrm{a}}$ \\
Fat & $3.23^{\mathrm{a}}$ & $3.04^{\mathrm{a}}$ \\
Protein & $12.11^{\mathrm{b}}$ & $15.05^{\mathrm{a}}$ \\
Crude fiber & $9.52^{\mathrm{a}}$ & $5.92^{\mathrm{b}}$ \\
Carbohydrates & $67.32^{\mathrm{a}}$ & $64.06^{\mathrm{b}}$ \\
\hline
\end{tabular}

${ }^{\mathrm{a}, \mathrm{b}}$ Different superscript letters in the same row indicate statistical difference $(\mathrm{p}<0.05)$. Data are the mean of three determinations. with a high content of linolenic acid (21.59 g/100g). Varieties of $S$. rebaudiana contain similar amounts of fat, so that could be an important source of linolenic acid. The protein content of both varieties was higher than reported by Abou-Arab et al. [20] that reported (11.4\%) for leaves of $S$. rebaudiana from Egypt; these authors identified seventeen amino acids, including all of the indispensable amino acids whit the exception of tryptophan. With high levels of protein the varieties of $S$. rebaudiana could be a valuable source of indispensable amino acids for health products. Braz de Oliveira et al. [21] isolated from root and leave of $S$. rebaudiana inulin-type fructooligosaccharides, a naturally occurring plant polysaccharide with important functional properties related to prebiotics, dietary fiber, role lipid metabolism and diabetes control. $S$. rebaudiana are a good source of carbohydrates and crude fiber, this indicates a possible application of leaf powder as a dietary supplement

\subsection{Total (TDF), Soluble (SDF) and Insoluble (IDF) Dietary Fiber}

Dietary fiber is the edible parts of plants or analogous carbohydrates that are resistant to digestion and absorption in the human small intestine with complete or partial fermentation in the large intestine [22]. Dietary fiber includes polysaccharides, oligosaccharides, lignin and associated plant substances. In addition an analogous carbohydrate is defined as those carbohydrates-based food ingredients that are non-digestible and non-absorbable, and which are similar to plant dietary fiber [23]. The adequate intake of dietary fiber through the high consumption of fruits and vegetables makes possible to achieve a healthy diet, a correct body weight, an acceptable lipoprotein profile, and a normal blood pressure [24]. TDF content in the $S$. rebaudiana leaf powders were 28.61 (Morita II) and 29.12 (Criolla) g/100g sample, with most of this content represented by IDF $87.79 \%$ in Morita II leaf powder and $70.02 \%$ in Criolla leaf powder. The remainder was constituted by SDF (Figure 2).

Dietary fiber has been widely studied for its health benefits. It is considered a preventive factor for cancer, serves as a substrate for colonic bacteria, promotes intestinal food transit, and decreases bile acid reabsorption thereby altering micelle formation and contributing to lowering blood cholesterol levels [25]. The S. rebaudiana leaf powders differed in their IDF/SDF proportion 8.47 for Morita II and 2.33 for Criolla. The relatively high IDF percentages in S. rebaudiana Morita II leaf powder suggest possible applications in dietetic physiological products. Intake of this kind of fiber is linked to a sensation of satiety, since as the fiber absorbs water it takes up space in the stomach and diminishes the need to consume more food. It also increases the volume and 


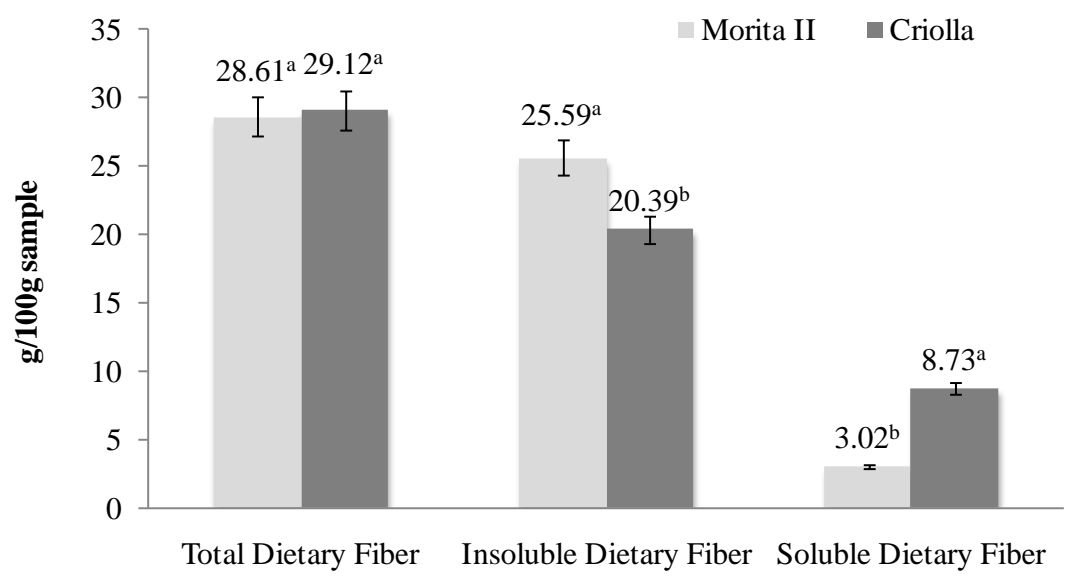

Figure 2. Dietary fiber fractions of Stevia rebaudiana (Bertoni) varieties (g/100g sample). ${ }^{\mathrm{a} b} \mathrm{Different}$ superscript letters in the same property indicate statistical difference $(p<0.05)$. Data are the mean \pm standard deviation.

weight of the fecal bolus, promoting improved functioning of the digestive system and preventing disorders such as constipation and colon cancer.

\subsection{Fiber Components}

Neutral detergent fiber and acid detergent fiber are widely used analytical methods for the estimation of the nutritive qualities of feed. They were originally proposed by Van Soest [26], but have undergone significant changes over the years [10]. Van Soest's fractionation makes it possible to measure the total cell wall content (NDF), lignocellulose content (ADF) and lignin content (ADL). In particular, $\mathrm{ADF}$ determination allows the evaluation of practically all the cellulose and lignin. Because of the long history of these methods, there exist large amounts of NDF and ADF data for many different potential cellulosicethanol feed stocks. Briefly, both techniques reflux a sample of biomass in a boiling aqueous surfactant solution. The NDF solution is kept at neutral $\mathrm{pH}$, while the ADF solution contains $1.00 \mathrm{~N}$ sulfuric acid. After refluxing for $1 \mathrm{~h}$, the solids are filtered, rinsed multiple times with water and acetone, and then dried. The remaining biomass is weighed, and reported as either a fractional value remaining (\%), or in $\mathrm{g} / \mathrm{kg}$ (parts-perthousand, ppt). A related procedure, acid detergent lignin, is performed on samples after the ADF procedure, and uses concentrated $(72 \% \mathrm{w} / \mathrm{v})$ sulfuric acid to dissolve any remaining structural carbohydrates, leaving insoluble lignin. Figure 3 shows NDF, ADF and ADL content of $S$. rebaudiana varieties. NDF includes mainly insoluble hemicellulose, cellulose, lignin and cutin. The NDF content was slightly higher in creole variety. On the other hand, ADF that include principally cellulose, lignin and cutin, and ADL that include lignin and cutin were higher in creole variety. Figure 4 shows the hemicellulose and cellulose contents of $S$. rebaudiana varieties. Both com- ponents were higher in Morita II variety. Hemicellulose content was estimated by difference between NDF and ADF. Cellulose content was estimated by difference between ADF and ADL. The properties of hemicellulose may be important in human physiology. This fraction is largely degraded in the colon and has been reported to increase fecal output. Hemicellulose has other important properties such as ion-binding capacity and water-holding capacity. The effects of fiber components has been demonstrated in different studies as realized by Hillman et al. [27] who demonstrated that dietary supplementation with maximally tolerated amounts of pectin, cellulose or lignin is associated with significant changesin serum cholesterol levels in healthy normolipidemic subjects in the short term. In general, dietary fiber has been recognized as a healthy food component. Health benefits associated with adequate intake of substances as cellulose, hemicellulose and lignin include: lower blood cholesterol and sugar levels, reduced risk of constipation, obesity, diabetics, heart complications, colon and rectal cancer, gallstone, piles and hernia. These health benefits reflect the nutritional significance of dietary fiber, and have attracted the consumer to fiber rich foods. Public health organization also recommended an increase in the daily consumption of dietary fiber [28]. For these reasons, the determination of the dietary fiber content of food as Stevia has been receiving much attention for the last few years.

\subsection{Functional Properties}

Figure 5 showed the functional properties of S. rebaudiana leaf powders from Morita II and Criolla varieties. Morita II showed higher values of water holding and organic molecule absorption capacity than Criolla variety. The water holding capacity of the Stevia leaf powders may be due to the high protein content (Table 1). 


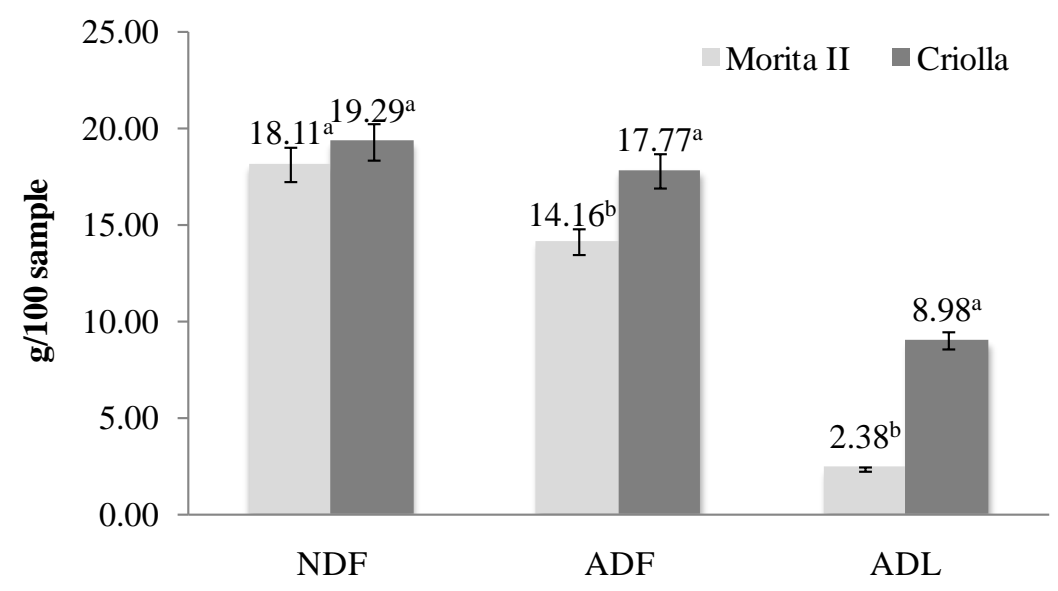

Figure 3. Neutral Detergent Fiber (NDF), Acid Detergent Fiber (ADF) and Acid Detergent Lignin (ADL) content of Stevia rebaudiana (Bertoni) varieties. ${ }^{a, b}$ Different superscript letters in the same property indicate statistical difference $(p<0.05)$. Data are the mean \pm standard deviation.

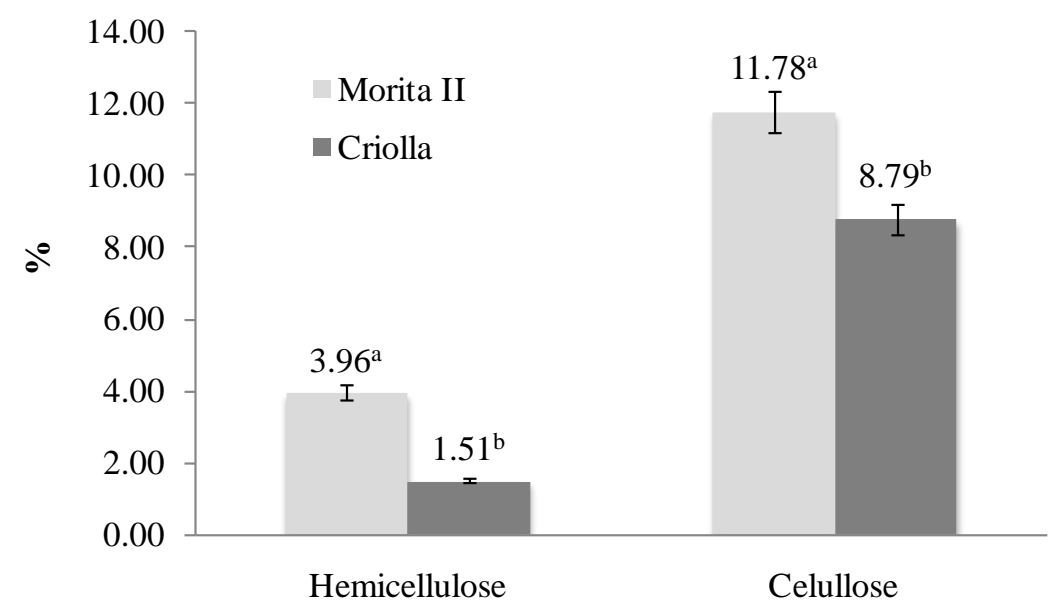

Figure 4. Hemicellulose and cellulose content of Stevia rebaudiana (Bertoni) varieties. ${ }^{\text {a,b }}$ Different superscript letters in the same property indicate statistical difference $(p<0.05)$. Data are the mean \pm standard deviation.

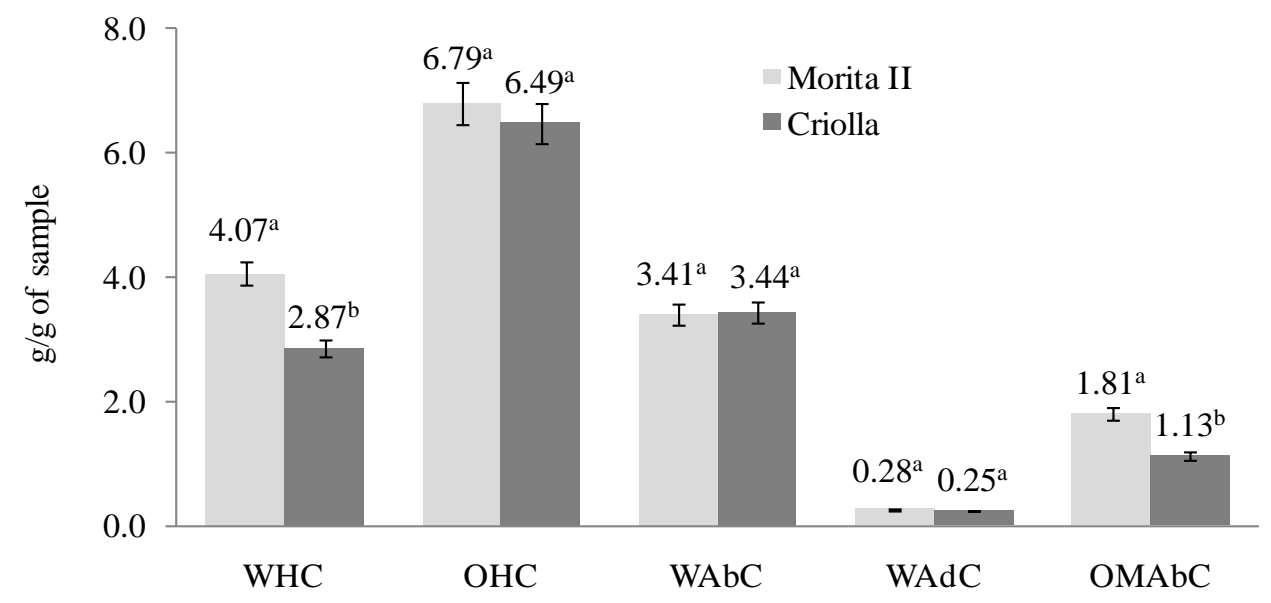

Figure 5. Functional properties of Stevia rebaudiana (Bertoni) leaf powder. Water Holding Capacity (WHC), Oil Holding Capacity (OHC), Water Absorption Capacity (WAbC), Water Adsorption Capacity (WAdC), and Organic Molecule Absorption Capacity (OMAbC). ${ }^{\text {a,b }}$ Different superscript letters in the same property indicate statistical difference $(p<0.05)$. Data are the mean \pm standard deviation. 
Proteins would increase water holding capacity, thus enhancing the swelling ability [29], an important function of protein in preparation of viscous foods such as soups, gravies, dough and baked products.

Both varieties showed similar oil holding capacity (Figure 5), this functional property has been attributed to the physical entrapment of oil. Stevia leaf powders seems to possess an adequate fat absorption capacity, allowing it to play an important role in food processing, since fat acts on flavor retainers and increases mouth feel of foods [30]. The $S$. rebaudiana leaf powders had similar values of water absorption capacity (WAbC) (3.4 g/g sample) and water adsorption capacity (WAdC). Water absorption capacity is indicative of a structure's aptitude to spontaneously absorb water when placed in contact with a constantly moist surface or when immersed in water and water adsorption capacity is the ability of a structure to spontaneously adsorb water when exposed to an atmosphere of constant relative humidity. It is initially a surface phenomenon but at higher hydration levels absorption can occur inside the structure, leading to swelling and eventual solubilization [14]. In this case, the proteins would have a large number of exposed hydrophilic sites that could be interacting with water and increasing WAbC [31].

The $S$. rebaudiana leaf powders showed values of water adsorption capacity of 0.28 and $0.25 \mathrm{~g}$ water/g sample, which are substantially lower than values for carrot $(0.82$ g water/g sample) and beet (1.58 g water/g sample) [14]. The insoluble dietary fiber is responsible for most WAdC since it adsorbs water like a sponge; however, no direct relation between IDF and WAdC was observed here. The $S$. rebaudiana organic molecule absorption capacities (OMAbC) were 1.81 and $1.13 \mathrm{~g} / \mathrm{g}$ sample. Given this OMAbC values, the $S$. rebaudiana leaf powders could function efficiently interacting with fats, biliar acids, cholesterol, drugs and even toxic or carcinogenic compounds at the intestinal level and then be eliminated in the feces. Lignin, an IDF component, is probably the main compound responsible for OMAbC [32], in the $S$. rebaudiana powders since it is among the fiber components with the highest capacity to link to organic molecules.

\section{Conclusion}

Stevia rebaudiana (Bertoni) leaf powders from Morita II and Criolla varieties cultivates in Mexican Southeast are good sources of carbohydrates, protein and dietary fiber which are vital for human nutrition and maintain a good health. It is suggested that they may be used in enhancing the nutritive value of low nutrient density foods. Beside their functional properties indicate that could be applied as binders or extenders in food systems.

\section{Acknowledgements}

This publication forms part of the projects "Evaluación del efecto hipoglucemiante de las hojas de Stevia rebaudiana" funded by Programa de Mejoramiento al Profesorado-PROMEP-SEP; "Caracterización quimica de las hojas de Stevia rebaudiana y su incorporación en alimentos" supported by Fundación Educación Superior Empresa (FESE) and "Desarrollo de productos alimenticios elaborados con hoja de Stevia rebaudiana Bertoni” funded by Fondos Fiscales-INIFAP.

\section{REFERENCES}

[1] S. Singh, V. Garg, D. Yadav, M. N. Beg and N. Sharma, "In Vitro Antioxidative and Antibacterial Activities of Various Parts of Stevia rebaudiana (Bertoni)," International Journal of Pharmacy and Pharmaceutical Sciences, Vol. 4, No. 3, 2012, pp. 468-473.

[2] J. Atteh, O. Onagbesan, K. Tona, J. Buyse, E. Decuypereand and J. Geuns, "Potential Use of Stevia rebaudiana in Animal Feeds,” Archivos de Zootecnia, Vol. 60, No. 229, 2011, pp. 133-136. http://dx.doi.org/10.4321/S0004-05922011000100015

[3] J. M. C. Geuns, P. Augustijns, R. Mols, J. C. Buyse and B. Driessen, "Metabolism of Stevioside in Pigs and Intestinal Absorption Characteristics of Stevioside, Rebaudioside A and Steviol," Food and Chemical Toxicology, Vol. 41, No. 11, 2003, pp. 1599-1607. http://dx.doi.org/10.1016/S0278-6915(03)00191-1

[4] S. Shukla, A. Mehta, V. K. Bajpai and S. Shukla, "In Vitro Antioxidant Activity and Total Phenolic Content of Ethanolic Leaf Extract of Stevia rebaudiana Bert," Food and Chemical Toxicology, Vol. 47, No. 9, 2009, pp. 23382343. http://dx.doi.org/10.1016/j.fct.2009.06.024

[5] A. O. Fasuy and V. A. Aletor, "Varietal Composition and Functional Properties of Cassava (Manihotesculenta, Cranzt) Leaf Meal and Leaf Protein Concentrates," $\mathrm{Pa}$ kistan Journal of Nutrition, Vol. 4, No. 1, 2005, pp. 4349. http://dx.doi.org/10.3923/pjn.2005.43.49

[6] O. Aletor and A. O. Adebayo, "Nutritive and Physicochemical Characteristics of the Leaves and Leaf Protein Concentrates from Two Edible Vegetables: A Comparative Evaluation," World Journal of Dairy and Food Sciences, Vol. 7, No. 1, 2012, pp. 54-58.

[7] J. G. Ramírez, B. W. Avilés, O. Y. Moguel, G. S. Góngoranad and L. C. May, "Stevia (Stevia rebaudiana Bertoni) a Growing with Productive Potential in Mexico," National Institute of Forestry, Agriculture and Livestock, Southeast Regional Research Center, Merida, Yucatán, Mexico, 2011.

[8] AOAC, "Official Methods of Analysis, Association of Official Analytical Chemists,” AOAC, Arlington, 1998.

[9] L. Prosky, N. Asp, T. Schweizer, S. Devries and I. Furda, "Determination of Insoluble, Soluble and Total Dietary Fiber in Food and Food Products: Interlaboratory Study," Journal of the Association of Official Analytical Chemists, 
Vol. 71, No. 5, 1998, pp. 1017-1023.

[10] P. J. Van Soest, J. B. Robertson and B. A. Lewis, "Methods for Dietary Fiber, Neutral Detergent Fiber, and Nonstarch Polysaccharides in Relation to Animal Nutrition,” Journal of Dairy Science, Vol. 74, No. 10, 1991, pp. 3583-3597.

http://dx.doi.org/10.3168/jds.S0022-0302(91)78551-2

[11] AOAC, "Fiber (Acid Detergent) and Lignin in Animal Feed. (973.18)," 15th Edition, Association of Official Analytical Chemists, Washington DC, 1990.

[12] C. F. Chau, K. C. P. Cheung and Y. S. Wong, "Functional Properties of Protein Concentrates from Three Chinese Indigenous Legume Seeds,” Journal of Agricultural and Food Chemistry, Vol. 45, No. 7, 1997, pp. 2500-2503. http://dx.doi.org/10.1021/jf970047c

[13] J. Chen, M. Piva and T. P. Labuza, "Evaluation of Water Binding Capacity (WBC) of Food Fiber Sources,” Journal of Food Science, Vol. 49, No. 1, 1984, pp. 59-63. http://dx.doi.org/10.1111/j.1365-2621.1984.tb13668.x

[14] M. Zambrano, R. Meléndez and Y. Gallardo, "Propiedades Funcionales y Metodología Para su Evaluación en Fibra Dietética,” In: F. Lajolo, F. Saura-Calixto, E. Witting and E. Wenzel-Varela, Eds., Fibra Dietética en Iberoamérica: Tecnología y Salud, Livraría LTDA Brasil, Sao Paulo, 2001, pp. 195-209.

[15] D. Montgomery, "Diseño y Análisis de Experimentos,” Limusa-Wiley, Mexico City, 2004

[16] K. Rahmesh, V. Singh and N. Megeji, "Cultivation of Stevia (Stevia rebaudiana (Bert) Bertoni): A Comprehensive Review," Advances in Agronomy, Vol. 89, No. 1, 2006, pp. 137-177.

[17] D. Adotey, Y. Serfor-Armah, J. Fianko and P. Yeboah, "Essential Elements Content in Core Vegetables Grown and Consumed in Ghana by Instrumental Neutron Activation Analysis," African Journal of Food Science, Vol. 3, No. 9, 2009, pp. 243-249.

[18] P. Mishra, R. Singh, U. Kumar and V. Prakash, "Stevia rebaudiana-A Magical Sweetener," Global Journal of Biotechnology and Biochemistry, Vol. 5, No. 1, 2010, pp. 62-74.

[19] M. Tadhani and R. Subhash, "Preliminary Studies on Stevia rebaudiana Leaves: Proximal Composition, Mineral Analysis and Phytochemical Screening," Journal of Medical Sciences, Vol. 6, No. 3, 2006, pp. 321-326. http://dx.doi.org/10.3923/jms.2006.321.326

[20] A. Abou-Arab and M. F. Abu-Salem, "Physico-Chemical Assessment of Natural Sweeteners Steviosides Produced from Stevia rebaudiana Bertoni Plant,” African Journal of Food Science, Vol. 4, No. 5, 2010, pp. 269-281.

\section{Abbreviations}

ADF: Acid Detergent Fiber; ADL: Acid Detergent Lignin; ANOVA: Analysis of Variance; AOAC: Association of Official Analytical Chemists; IDF: Insoluble Dietary Fiber; NDF: Neutral Detergent Fiber; NFE: Nitrogen-Free
[21] A. J. B. de Oliveira, R. A. C. Gonçalves, T. P. C. Chierrito, M. M. dos Santos, L. M. de Souza and P. A. J. Gorin, "Structure and Degree of Polymerisation of Fructooligosaccharides Present in Roots and Leaves of Stevia rebaudiana (Bert.) Bertoni,” Food Chemistry, Vol. 129, No. 2, 2011, pp. 305-311.

[22] A. Sankhala, A. K. Sankhala, B. Bhatnagar and A. Singh, "Nutrient Composition of Less Familiar Leaves Consumed by the Tribals of Udaipur Region," Journal of Food Science and Technology, Vol. 42, No. 5, 2005, pp. 446448.

[23] L. Prosky, "What Is Dietary Fiber? A New Look at the Definition,” In: B. V. Cleary and L. Prosky, Eds., Advanced Dietary Fiber Technology, Blackwell Science Oxford, 2001, pp. 63-88.

[24] F. J. Sánchez-Muñiz, "Dietary Fiber and Cardiovascular Health,” Nutrición Hospitalaria, Vol. 27, No. 1, 2012, pp. 31-45.

[25] E. Escudero-Álvarez and P. González-Sánchez, "La Fibra Dietética,” Nutrición Hospitalaria, Vol. 21, No. 2, 2006, pp. 61-72.

[26] P. J. Van Soest, "Use of Detergents in Theanalysis of Fibrousfeeds. II. A Rapid Method for the Determination of Fiber and Lignin," Journal of the Association of Official Analytical Chemistry, Vol. 46, No. 1, 1963, pp. 829-835.

[27] L. C. Hillman, S. G. Peters and A. Fisher, "The Effects of the Fiber Components Pectin, Cellulose and Lignin on Serum Cholesterol Levels," The American Journal of Clinical Nutrition, Vol. 42, No. 2, 1985, pp. 207-213.

[28] A. R. Khan, S. Alam, S. Ali, S. Bibi and I. A. Khalil, "Dietary Fiber Profile of Food Legumes," Sarhad Journal of Agriculture, Vol. 23, No. 3, 2007, pp. 763-766.

[29] S. M. Savita, K. Sheela, S. Sunanda, A. G. Shankar and P. Ramakrishna, "Stevia rebaudiana-A Functional Component for Food Industry,” Journal of Human Ecology, Vol. 15, No. 4, 2004, pp. 261-264.

[30] B. Crammer and R. Ikan, "Sweet Glycosides from the Stevia Plant,” Chemistry in Britain, Vol. 22, No. 10, 1986, pp. 915-917.

[31] H. Yeh, N. Su and M. Lee, “Chemical Compositions and Physicochemical Properties of the Fiber-Rich Materials Prepared from Shoyu Mash Residue,” Journal of Agricultural and Food Chemistry, Vol. 53, No. 11, 2005, pp. 4361-4366.

[32] W. D. Rosamond, "Dietary Fiber and Prevention of Cardiovascular Disease," Journal of the American College Cardiology, Vol. 39, No. 1, 2002, pp. 57-59.

Extract; OHC: Oil-Holding Capacity; OMAbC: Organic Molecule Absorption Capacity; TDF: Total Dietary Fiber; SDF: Soluble Dietary Fiber; WAbC: Water Absorption Capacity; WAdC: Water Adsorption Capacity; WHC: Water-Holding Capacity. 